\title{
School Administrators' Relationships with Academic Studies carried out in Educational Administration and Scholars
}

\author{
İbrahim Hakan KARATAŞ ${ }^{*}$ Jiydegul Alymidin KYZY ${ }^{* *}$ Cemrenur TOPUZ $^{* * *}$
}

Received: 12 March 2014

Accepted: 26 August 2014

\begin{abstract}
The study aims at determining the extent of implementation of the theories and research on educational administration. It analyzes the school administrators' relationships with research studies carried out on educational administration and scholars. The questionnaire used in the survey was applied to 310 school principals and assistant principals in primary and secondary schools in Istanbul. The study has found that the institutional collaboration between scholars and school administrators is weak. It was revealed that the majority of school administrators began office without any specific training in school administration; that they did not follow at all or rarely followed research studies on school administration; that the research studies did not address real problems in schools; that researchers were not interested in knowing schools better; that they felt their attempts to implement research studies were thwarted by their superiors and present regulations; and they had limited access to scientific studies.
\end{abstract}

Keywords: educational administration, school principals, theory and practice

\section{Extended Abstract}

Purpose and Significance: The study aims at determining the extent of implementation of the theories and research on educational administration. It analyzes the school administrators' relationships with research studies carried out on educational administration and scholars. The study sought the answers for the following questions.

1. Which foreign languages do the school administrators know and at what level?

2. What type of training did the school administrators receive in the field of educational administration?

3. What kind of a relationship among school administrators, scholars and scientific studies are made in the field of educational administration?

4. What are the obstacles/barriers in the relationship between school administrators and scientific studies conducted in the field of educational administration?

5. What is the number and quality of scientific research and scientists that school administrators reached in the last year?

This research is important in terms of conducting school administration according to scientific findings and determining the obstacles in its development.

\footnotetext{
* Corresponding Author: Assist. Prof. Dr., Fatih University, Istanbul, Turkey, ihkaratas@gmail.com

** Lecturer, Fatih University, Istanbul, Turkey, jiydegul@ fatih.edu.tr

**** Research Assistant, Fatih University, Istanbul, Turkey, cemre_topuz@yahoo.com
} 
Research findings, will be very useful in terms of introducing school administrators' perception of scientific studies and scholars. Especially, it provides the information about what training techniques are effective and acceptable in their professional development.

Istanbul has significant advantages in terms variety of opportunities for professional development of school administrators in Turkey. This research conducted on the school administrators in Istanbul, which is full of universities, publishing houses and scientific events will give an idea about the situation in other cities in Turkey. This research is limited to five districts in Istanbul and the questions in the survey.

Methods: As the study aims at describing the current situation it uses a survey model. The population of the study constitutes the 2010-2011 academic year school principals and assistant principals who work in public and private elementary and secondary schools in Istanbul. The sample consists of 310 school administrators designated by stratified sampling method. Arnavutköy, Bakırköy and Sultangazi from European side of Istanbul and from Asian side Sultanbeyli and Üsküdar districts were chosen as a stratified sample taking the number of population and socio-economic levels of those districts into considerations.

The instrument: Data were collected through 26-item questionnaire developed by the researchers in the light of the literature. The survey is divided into five sections and used three different types of questions- multiple choice questions, open ended questions and Likert style questions. In addition, there is a section including demographic information of the participants as gender, duty, experience, type of school, and education.

Results: The research findings were presented under five subheadings in the framework of research questions: (1) In terms of foreign languages, even though vast majority (87.4\%) of the participants stated that they master English, only 10,3\% of them indicated that their English is advanced. Moreover, most of those people whose English is more fluent have only 1-5 year experience and work as assistant principals. Majority of school administrators do not have the chance to follow the publications in their original languages and to communicate with their foreign colleagues. (2) $85.5 \%$ of school administrators stated that they did not take education in the field of school administration, or they participated in short training programs. This shows that school administrators in Turkey substantially learned through trial and error after they start. Nevertheless, the number of the administrators with post graduate degree $(13.1 \%)$ should not be underestimated. (3) Vast majority of school administrators (\%70.9) stated that they do not follow scholars and scientific publications regularly. $29.1 \%$ of them indicated that they at least once a month apply for the scientific studies and scholars. (4) The findings related to the barriers between school administrators and pedagogues who carry out research in this field were studied under four sub-headings. They are (a) barriers that arise from the quality of scientific research; (b) barriers originated from 
pedagogs; (c) barriers that are related to school administrators; (d) and other obstacles. (5) To the question related to the number of books and publications, about school administration, they have read in the last academic year $84.6 \%$ of the participants did not write anything. $11.6 \%$ of the participants stated the names of the books related to educational administration, management or educational sciences. While only $5.8 \%$ of this were directly related to school administration $3,8 \%$ of the participants wrote the names of the works that are not related to educational administration at all.

Discussion and Conclusions: Research offers significant findings for school administrators, academics and education administrators. It can be said that school administrators do not possess a scientific management perspective. Also, it is clear that concerned academicians did not address to meet this need. The ministry of education must take urgent measures to resolve this situation.

However, it can be concluded that the actual burden is on the academicians. The fact that the school administrators are not aware of and do not utilize the scientific publications produced by the academicians should make the academicians think and review their scientific methods and their field of study. In addition, it should be noted that one of the basic functions of universities is to produce solutions to the problems encountered in everyday life (Erdem, 2005).

On the other hand, it should be investigated that whether the fact that administrators do not follow scientific publications is related to other reasons, despite the fact that they in most cases start their work without having any education in or any in-service training educational administration.

In addition to the justifications found in this study, the lifelong learning skills and scientific literacy competencies of the school administrators should be investigated in terms of their effect on this situation. 


\title{
Okul Yöneticileri ile Eğitim Yönetimi Alanında Yapılan Bilimsel Araştırmalar ve Çalışan Bilim İnsanları Arasındaki İlişki
}

\author{
İbrahim Hakan KARATAŞ ${ }^{*} \quad$ Jiydegul Alymidin KYZY ${ }^{* *}$ Cemrenur TOPUZ $^{* * *}$
}

Makale Gönderme Tarihi: 12 Mart 2014

Makale Kabul Tarihi: 26 Ağustos 2014

ÖZET: Bu araştırma, Türkiye'de eğitim yönetimi alanında yapılan bilimsel araştırmaların uygulamaya ne düzeyde yansıdığını belirlemek için okul yöneticileri ile eğitim yönetimi alanında yapılan bilimsel çalışmalar ve çalışma yapan bilim insanları arasındaki ilişkinin niteliğini betimlemeyi amaçlamaktadır. Tarama modelinde gerçekleştirilen araştırmanın anketi, İstanbul'daki ilk ve ortaöğretim kurumlarında 2010-2011 öğretim yılında görev yapan 310 okul müdürüne uygulanmıştır. Araştırma sonucunda eğitim yönetimi alanında çalışma yapan akademisyenler ile okul yöneticileri arasında teorinin pratiğe aktarılması amacıyla kurumsal bir işbirliğinin zayıf olduğu belirlenmiştir. Okul yöneticilerinin büyük çoğunluğunun yabancı dil bilmediği, eğitim/okul yöneticiliğine dair bir eğitim almadan göreve başladıkları, eğitim yönetimi alanındaki bilimsel araştırmaları ya hiç izlemedikleri ya da çok seyrek izledikleri, bilimsel araştırmaların okuldaki gerçek sorunlara odaklanmadığı, bilim insanlarının okulu yakından tanıma gayretinde olmadıkları, mevzuatın ve üstlerinin bilimsel önerileri uygulamalarında kendilerini engellediği ve bilimsel çalışmalara ulaşmak için yeteri kadar maddi kaynaklarının olmadığı sonuçlarına ulaşılmıştır.

Anahtar Sözcükler: Eğitim yönetimi, okul yöneticileri, kuram ve uygulama

\section{Giriş}

Türkiye'de eğitim bilimleri alanında yapılan bilimsel araştırmaların genel olarak eğitim politikalarına ve eğitim yönetimine, özel olarak ise okul yönetimine beklenen düzeyde yansıyıp yansımadığı önemli tartışma konularından biridir. Eğitim yönetimi alanında yapılan çalışmalar okul yönetimine ve okul yöneticisinin yöneticilik bilgi, beceri ve tutumlarına ne düzeyde olumlu katkı sağlamakta ve neticede öğrenci başarısına ne düzeyde etki etmektedir? Okullar ile fakülteler arasında, okul yöneticileri ile alan akademisyenleri arasında, kuram ile uygulama arasında bir ilişki/irtibat var mıdır? $\mathrm{Bu}$ sorular fakülte-okul işbirliği ve kuram-uygulama ilişkisi kavramları çerçevesinde ele alınmaktadır.

Fakülte-okul işbirliği, geleneksel olarak, eğitim fakülteleri ile okullar arasında, aday öğretmenlerin uygulamalı eğitimlerini okullarda yapmalarını sağlamak amacıyla yürütülen işbirliği olarak kabul edilmektedir (Milli Eğitim Bakanlığı [MEB], 1998). Bu işbirliğinin uygulama sürecinin nasıl yürütüleceğini açıklayan fakülte okul işbirliği kılavuzu (Yükseköğretim Kurulu [YÖK], 1998) ile yasal boyutunu düzenleyen bir yönerge bulunmaktadır (MEB, 1998). Bu işbirliği, fakülte öğrencilerinin öğretim üyelerinin gözetimi altında belli bir süre okulda rehber öğretmenler eşliğinde öğretmenliği uygulamalı olarak öğrenmesini sağlamayı amaçlamaktadır. Fakat bu işbirliği sürecini ele alan birçok araştırma yapılmış ve genel olarak beklenen faydanın elde edilemediği ortaya çıkmıştır (Cerit Berber ve Oral, 2010; Eraslan, 2008; Güzel ve Güngördü, 1999).

\footnotetext{
* Sorumlu Yazar: Yrd. Doç. Dr., Fatih Üniversitesi, İstanbul, ihkaratas@gmail.com

*** Okutman, Fatih Üniversitesi, İstanbul, jiydegul@fatih.edu.tr

**** Araştırma Görevlisi, Fatih Üniversitesi, İstanbul, cemre_topuz@yahoo.com
} 
Fakülte okul işbirliğinde bunun ötesine giden uygulamalara da rastlanmaktadır. Amerika Birleşik Devletleri (ABD), 1983'te dönemin eğitim sistemini değerlendiren "A Nation at Risk" (Bir Ulus Tehlikede) adl raporun (The National Commission on Excellence in Education, 1983) ardından ulusal eğitimi etraflıca masaya yatırmıştır. Bu bağlamda bir çözüm önerisi olarak uygulamaya konulan girişimlerden biri de Profesyonel Okul Gelişimi (Professional Development School [PDS]) programı olmuştur (Hopkins-Malchow, 2009). 1990'lar boyunca süren uygulamada üniversiteler bölgelerindeki okullarla işbirliği geliştirmiş ve bu işbirliği sayesinde okulun sürekli gelişiminin sağlanması amaçlanmıştır (El-Amin, Cristol ve Hammond, 1999; Frampton, Vaughn ve Didelot, 2003; Hopkins-Malchow, 2009). Çin Hong Kong Üniversitesi tarafından geliştirilen bir program çerçevesinde benzer bir uygulama 1998'de Hong Kong'da başlatılmıştır. Kaliteli Eğitim için Hızlandırılmış Okullar (Accelerated Schools for Quality Education [ASQE]) adıyla yürütülen program, okullardaki başarısızlıkları azaltmak ve sürekli kaliteli eğitimi sağlamayı amaçlamaktadır (Chiu, 2006).

Türkiye'de de 1999'dan itibaren fakülte-okul işbirliği kavramı yaygınlaşmıştır. Yukarıda söz edildiği üzere eğitim fakülteleri ile ilgili düzenlemeler çerçevesinde aday öğretmenler için uygulama derslerinin artırılması ile gündeme gelen işbirliği aynı yıl eğitim yöneticilerin seçme ve atama yönetmeliğinin değiştirilmesi ile eğitim ve okul yöneticileri alanında da söz konusu olmuştur. Atanan okul yöneticilerinin göreve başlamadan önce 120 saatlik bir eğitim almaları zorunlu hale getirilmiştir (MEB, 1998). Yedinci ve Ondördüncü Milli Eğitim Şuralarında eğitim yöneticiliği konusu etraflıca tartış1lmış ve önemli kararlar alınmış olsa da (Deniz, 2001) ancak 1998'de uygulamaya konulan bu yönetmelikle ilk kez eğitim yöneticileri için hizmet öncesi bir eğitim şartı getirilmiştir. Çok verimli ve faydalı olmayan (Bakioğlu ve Özcan, 2001) ve kısa süre içinde uygulamadan kaldırılan bu örneğin ardından 2011'in güz döneminde Bakanlık yayınladığı bir genelge ile merkez ve taşra teşkilatındaki yöneticilerin çevredeki üniversitelerle işbirliği yaparak seminerler düzenlenmesini ve böylece yöneticilerin mesleki gelişimlerinin sağlanmasına odaklanılmasını salık vermiştir (MEB, 2012).

Nitekim üniversiteler, eğitim-öğretim ve araştırma hizmetleri ile beraber esasen toplumun karşı karşıya kaldığı sorunlara bilimsel araştırmalar ışığında çözümler üretme sorumluluğunu da yerine getirmesi beklenen yapılardır (Erdem, 2005). Bilim insanları bu amaçla çağcıl bilimsel paradigmanın sınırları içerisinde geliştirilen yöntem ve tekniklerle bilimsel bilgi üretirler (Demir, 2000). Bilim insanlarının başarısı ve etkililiğinin önemli ölçütlerinden biri de belirlenmiş standartlar çerçevesinde ürettikleri bilgilerin ve geliştirdikleri çözüm önerilerinin gündelik hayatın farklı alanlarına yansıma oranlarıdır. $\mathrm{Bu}$ yansıma literatürde "kuramın uygulamaya aktarılması" biçiminde kavramsallaştırılmıştır.

Kuram, sistematik olarak eğitim örgütlerinde davranış konusundaki düzenlilikleri betimleyen ve açıklayan birbiriyle ilişkili bir dizi kavramlar, varsayımlar ve genellemeler bütünüdür. Uygulama ise açı ya da örtük kuramların gerçekleştirilmesidir. Üzerinde durulması gereken konu, uygulamaya kaynaklık eden kuramın karşılaştığımız sorunlara uygunluğu ve etkililiğidir (Hoy ve Miskel, 2010: 3). 
Eğitim çok yönlü bir alandır (Erdoğan, 2004) ve eğitim hizmetleri, bireylerin, toplumun ve günlük yaşamın ihtiyaçları ve talepleri doğrultusunda (Hesapçığlu, 1989; Topçu, 2010) sürekli bir değişim ve dönüşüm potansiyeline sahip olmalıdır. Eğitimin bu talep ve ihtiyaçların farkında olması ve bunlara cevap verecek nitelikte olması (Arslan, 2002) bilim insanlarının yaptığı ve yapacağı bilimsel çalışmalarla belirlenir (Demir, 2000). Eğitim-öğretim hizmetlerinin etkililiği, verimliliği ve bu niteliklerin sürdürülebilirliği de eğitim yöneticilerinin, bilhassa okul yöneticilerinin hayat boyu öğrenme, bilimsel gelişmelerden haberdar olma ve sonuçta bilim insanlarınca geliştirilen modelleri uygulamaya yansıtmalarına bağlıdır (Leithwood ve Louis (1998)'den aktaran Hoy ve Miskel, 2010: 33).

Okul yöneticilerinin eğitim yönetimi alanında yapılan bilimsel çalışmalarla üretilen kuramları ve karşılaşılan sorunlara yönelik çözüm önerilerini izlemeleri, bu önerileri uygulamaya istekli olmaları, uygulama sırasında bilim insanlarının danışmanlığından yararlanmaları eğitim kurumlarının hızlı değişim ve dönüşüm sürecine ayak uydurmaları ve böylece bireysel ve toplumsal beklentileri karşılamaları kolaylaşacaktır (Ensari, 2004). Fakat bunu engelleyen çift taraflı sebeplerden söz edilmektedir. (1) Turan (2010, xvii) eğitim yönetimi alanında yapılan araştırmaların, sağlam teorik temelden ve pratikte karşılaşılan sorunların çözümüne rehberlik edebilme açılarından sorunlu olduğunu savunur. Ona göre uygulamadaki sorunlara çözüm üretemeyen eğitim yönetimi araştırmacıları; "eğitimsel sorunları dışarıdan seyreden, bilim için bilim yapan fildişi kulede tek başına def çalan bir Anadolu dervişini andırmaktadır". Turan'ın Türkiye için betimlediği durum başta ABD olmak üzere başka gelişmiş ülkelerde de tartışılmaktadır. Whitaker (1996) okul yöneticisi yetiştirme programlarının, okul müdürlüğünün gerektirdiği nitelikleri kazandırma gücünden yoksun olduğunu belirtmektedir. Al (2008) ise Türkiye'deki bilimsel araştırmaları genel olarak ele aldığı araştırmasında bilimsel araştırmalarda nitelikten çok nicelik kaygısının ön planda olduğunu belirtmektedir. Özel olarak eğitim bilimleri alanında da araştırmacıların yaşadığı çeşitli sorunlar, ortaya çıkan kuramsal bilginin ve araştırma sonuçlarının uygulamaya etkisini düşürmektedir. Son yıllarda yapılan bir araştırmada, eğitim bilimleri alanında çalışma yapan akademisyenlerin ders yükü, yabancı dil yetersizliği, hızlı yayın yapma, kurumsal işbirliği eksikliği gibi gerekçelerle çalışmalarını istedikleri düzeyde nitelikli olarak tamamlayamadıklarını göstermektedir (Özdemir, 2009).

Okul yöneticilerinden kaynaklanan bazı durumların da kuram ile uygulama arasındaki kopukluğa neden olduğu belirtilmektedir. (2) Alanda yapılan araştırmaların uygulamaya yansıması okul yöneticilerinin bilimsel okuryazarlık becerileri ile de ilişkilidir. Bu noktada en dikkat çekici husus bilim okuryazarlığı becerisindeki eksikliktir. Okul yöneticilerinin bir bilimsel metnin veya bir araştırma raporunun nasıl “okunacağı”, pratiğe nasıl aktarılacağı konusunda da yeterlilik sahibi olmaları gerekmektedir. Miller'in (2006) Avrupa'nın birçok ülkesini de kapsayan araştırmasında Türkiye'de yetişkinler arasındaki bilimsel okuryazarlık oranı $\% 2$ olarak en düşük düzeylerde bulunmuştur. (3) Okul yöneticilerinin yaşam boyu öğrenmeyi içselleştirmiş 
olmaları doğrudan kendi işlerini başarılı bir biçimde yapmalarına olanak sağlayacağı gibi dolaylı olarak da okulun bir öğrenen örgüt olmasına ve öğretmenlerin mesleki gelişimlerini sürdürmelerine de katkısı olacaktır (Mullen ve Hutinger, 2008). (4) Kuram-uygulama arasındaki kopukluk okulun örgütsel yapısı ile ilgili koşul ya da sorunlardan da kaynaklanabilmektedir. Okulun büyüklüğü, farklı zümrelerden ve bölümlerden oluşuyor olması, okul müdürü sirkülasyonu, öğretmenlerin, aday öğretmenlerin eğitimine ilişkin görüşleri (Bullough Jr ve Kauchak, 1997) bu sorun alanları arasında sayılmaktadır. (5) Son olarak kuram uygulama arasındaki ilişkinin zayıf olması, kurumsal işbirliği sürecinin sağlıklı yapılandırılmadan başlatılmış olmasından da kaynaklanabilmektedir. İki kurum arasındaki profesyonel işbirliği sürecinin detaylıca yapılandırılması, karşı1ıklı hak ve sorumlulukların açıkça belirlenmesi ve hatta protokollerin imzalanması önerilmektedir. Zira üniversite okul işbirliği; eşitlik, karşılıklı öğrenme ve amaç uyumu ilkeleri gerçekleştiğinde başarılabilir. Üniversite okul işbirliğinde iki bağımsız kurum işbirliği yapmaktadır ve üstünlük söz konusu değildir. Üniversiteler okullara, okullar da üniversitelere bazı ihtiyaçlarını gidermek açısından bağımlıdır (Doğan, 2009; El-Amin, Cristol ve Hammond, 1999; Erdoğan, 2004).

$\mathrm{Bu}$ araştırma, eğitim yönetimi alanında yapılan bilimsel araştırmaların, okul yönetimlerine yansıma düzeyini belirleyebilmek için okul yöneticileri ile eğitim yönetimi alanında yapılan bilimsel çalışmalar ve çalışma yapan bilim insanları arasındaki ilişkinin niteliğini analiz etmeyi amaçlamaktadır. Araştırmada aşağıdaki sorulara yanıt aranmıştır:

1. Okul yöneticileri hangi yabancı dilleri ne düzeyde bilmektedirler?

2. Okul yöneticileri, eğitim yönetimi alanında ne tür bir eğitim almışlardır?

3. Okul yöneticileri ile eğitim yönetimi alanında yapılan bilimsel çalışmalar ve bilim insanları arasında ne tür bir ilişki bulunmaktadır?

4. Okul yöneticileri ile eğitim yönetimi alanında yapılan bilimsel çalışmalar ve bilim insanları arasındaki ilişkinin engelleri nelerdir?

5. Okul yöneticilerinin son bir yıl içinde ulaştıkları eğitim yönetimi alanında yapılan bilimsel çalışma ve bilim insanlarının sayısı ve niteliği nedir?

$\mathrm{Bu}$ araştırma, okul yönetiminin bilimsel veriler ve bulgular 1şığında yürütülmesi ve geliştirilmesinin önündeki engelleri belirlemek açısından önem arz etmektedir. Araştırma bulguları, okul yöneticilerinin bilimsel çalışmalara ve bilim insanlarına yönelik algılarını ortaya koyması bakımından da üniversiteler açısından oldukça yararlı olacaktır. Ayrıca okul yöneticilerinin mesleki gelişimlerini sağlamak amacıyla hangi yöntemlerin daha işlevsel ve kabul edilebilir olduğu da görülecektir. Türkiye'de okul yöneticilerinin görev başında mesleki gelişmelerini sürdürmelerini sağlayacak imkanların zenginliği bakımından İstanbul önemli avantajlara sahiptir. Üniversiteler, yayınevleri ve bilimsel etkinlikler bakımından oldukça hareketli olan İstanbul'daki okul yöneticileri üzerinde yapılan bu araştırma diğer şehirlerdeki okul yöneticilerinin durumu hakkında da bir fikir verebilecektir. Bu araştırma İstanbul'daki beş ilçe ile ve ankette yer alan sorularla sinırlıdır. 


\section{Yöntem}

\section{Araştırma Modeli, Evren ve Örneklem}

Araştırma, var olan durumu betimlemeyi amaçladığından tarama modeli tercih edilmiştir. Araştırmanın evrenini 2010-2011 eğitim-öğretim yılında İstanbul'da resmi ve özel ilköğretim ve ortaöğretim kurumlarında görev yapmakta olan okul müdürleri ve müdür yardımcıları oluşturmaktadır. Örneklem tabakalı örneklem yöntemiyle belirlenen 310 okul yöneticisinden oluşmaktadır. Tabakalı örneklem seçiminde İstanbul'un nüfusları ve sosyo-ekonomik gelişmişlik düzeyleri dikkate alınarak Avrupa yakasından Arnavutköy, Bakırköy ve Sultangazi; Asya yakasından Sultanbeyli ve Üsküdar ilçeleri alınmıştır. Bu ilçelerden araştırmaya dahil edilen katılımcıların sayısı, okul sayılarına ve okul türlerine orantılı olarak belirlenmeye çalışılmıştır. ${ }^{1}$

Araştırmaya katılan okul yöneticilerinin demografik özellikleri Tablo 1'de görülmektedir. Araştırmada okul yöneticileri (1) cinsiyet, (2) görev, (3) yöneticilik kıdemi, (4) eğitim durumu, (5) görev yapmakta oldukları okul tipi, (6) görev yapmakta oldukları okul kademesi değişkenleri itibariyle belirlenmiştir. Eğitim yönetimi alanında yapılan çeşitli araştırmalarda bu değişkenlerin okul yöneticilerinin yöneticilik becerilerinde ve iç ve diş paydaşlarla ilişkilerinde istatistiksel olarak anlamlı farklılıkların gerekçesi olduğu bulgulanmıştır (Bakioğlu ve Özcan, 2010).

1 MEB tarafindan yayınlanan 2009-2010 yll istatistiklerine göre İstanbul'da 1621 ilköğretim ve 1074 ortaöğretim kurumu bulunmaktadır (MEB, 2010). Türkiye İstatistik Kurumu verilerine göre İstanbul'da 2011 yll nufusu 13.624.240 kişidir (TUIK, 2011). Istanbul nüfusunun yaklaşık \%25'i, tüm okulların yaklaşık \%15'i araştırmaya dahil edilen ilçelerde bulunmaktadır. 
Tablo 1

Katılımcıların Demografik Özelliklerine Göre Frekans ve Yüzdeleri

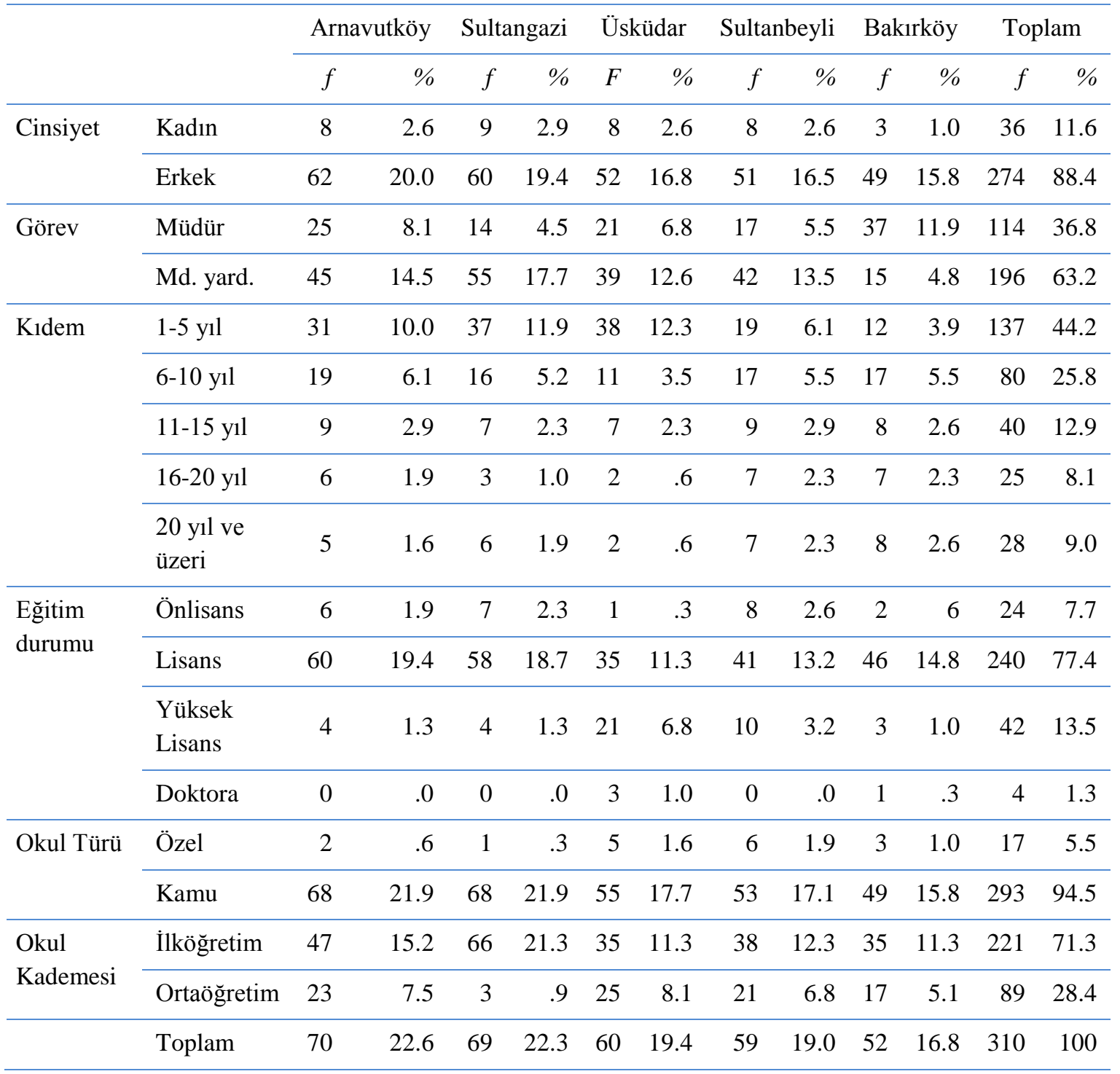

Araştırmaya İstanbul'un Arnavutköy (\%22.6), Sultangazi (\%22.3), Üsküdar (\%19.4), Sultanbeyli (\%19.0) ve Bakırköy (\%16.8) ilçelerindeki kamu ve özel ilköğretim ve ortaöğretim kurumlarında görev yapmakta olan 310 müdür ve müdür yardımcısı katılmıştır.

\section{Veri Toplama Aracı}

Araştırma verileri, araştırmacı tarafından ilgili literatür çerçevesinde geliştirilen, araştırmacılar dışındaki eğitim bilimcilerin görüşleri doğrultusunda son hali verilen 26 soruluk bir anket ile sağlanmıştır. Büyüköztürk'e (2005) göre bir dizi sorudan oluşan anketler dört aşamada hazırlanır: (1) problemi tanımlama, (2) taslak form oluşturma, (3) uzman görüşü alma ve (4) ön uygulama. Araştırmacılar tarafından ve ilgili alanyazın çerçevesinde oluşturulan anketin 40 maddelik ilk taslak formu alan uzmanı üç akademisyenin görüşüne sunulmuştur. Uzmanların görüşleri doğrultusunda gerekli 
düzenlemeler yapılmış ve soru sayısı 30'a indirilmiştir. İkinci aşamada ankette yer alan soruların anlaşılırlığı, cevaplanabilirliği, amaca uygunluğu ve güvenirliğinin belirlenmesi amaciyla İstanbul Üsküdar'da görev yapmakta olan 30 okul yöneticine ön uygulama yapılmıştır. Anketin ön uygulama formuna katılımcıların anketin anlaş1lırlığı, cevaplanabilirliği ve amaca uygunluğuna ilişkin görüş ve önerilerini yazmaları amacıyla bir bölüm eklenmiştir. Ön uygulama sonucunda geri dönen görüş ve öneriler sonunda ankete son hali verilmiştir.

Anket beş bölüme ayrılmış ve üç farklı soru tipi kullanılmıştır. Okul yönetimi ile bilimsel çalışmalar ve bilim insanları arasındaki ilişkinin (1) sıklığını ortaya çıkarmayı amaçlayan soru çoktan seçmeli, (2) gerekçeleri ve (3) yollarını ortaya çıkarmayı amaçlayan sorular birden çok cevaplı; (4) sorunların kaynağını ortaya çıkarmayı amaçlayan sorular beşli likert; (5) son bir yıl içinde hangi bilimsel çalışmalara ya da bilim insanlarına ulaşıldığını ortaya çıkarmaya çalışan sorular ise açık uçlu soru biçiminde hazırlanmıştır. Ayrıca katılımcıların cinsiyet, görev, mesleki kıdem, okul türü, eğitim durumu ve eğitim kademesi durumunu içeren demografik özelliklerini belirlemeye yönelik bir bölüm eklenmiştir.

\section{Verilerin Toplanması}

Veri toplanma aracı, İstanbul İl Milli Eğitim Müdürlügünün onayının alınmasının ardından İstanbul'un Arnavutköy, Bakırköy, Sultangazi, Üsküdar ve Sultanbeyli ilçelerinde tabakalı örneklem yoluyla belirlenen okul müdürlerine ve müdür yardımcılarına Ocak 2011'de elden ulaştırılmış ve doldurmaları istenmiştir. Toplam 500 okul müdürüne ve müdür yardımcısına ulaştırılan anketlerden 345'i Şubat 2011 içinde geri dönmüş ve 310 anket değerlendirmeye alınmıştır.

\section{Verilerin Analizi}

Araştırmada nicel verilerin analizinde frekans ve yüzde teknikleri kullanılmıştır. Bulgular verilerin yoğunlaştığı yöne göre değerlendirilmiştir. Nicel verilerin analizinde SPSS paket programı kullanılmıştır.

Anketin son bölümünde yer alan açı uçlu sorulara verilen cevapların analizinde içerik analizi yöntemi kullanılmıştır. Veriler iki aşamada analiz edilmiştir. İlk aşamada veriler her üç araştırmacı tarafından ayrı ayrı tasnif edilmiştir. Bu ilk tasnifte her iki soru ile elde edilen veriler eğitim yönetimi alanı, diğer eğitim bilimleri alanları, eğitim bilimleri dışındaki bilim alanları ve herhangi bir bilim alanına ait olmayanlar olmak üzere dört alt başlıkta listelenmiştir. İkinci aşamada üç farklı araştırmacı tarafından yapılan bu tasnifler karşılaştırılmış ve büyük oranda (\%90) benzerlik olduğu görülmüştür. Araştırmacılar arasındaki farklılıklar, eser ve kişi adlarının alanlarının araştırılması ve kesinleştirilmesi ardından diğer kategorisi de eklenerek altı başlık altında listelenmiştir. 


\section{Bulgular}

Araştırma bulguları, araştırma soruları çerçevesinde beş alt başlık altında sunulmuştur.

\section{Okul Yöneticilerinin Bildiği Yabancı Diller ve Düzeyleri}

Diğer birçok alanda olduğu gibi okul yöneticiliği ve eğitim yönetimi alanında yapılan bilimsel araştırmaların büyük kısmı İngilizce yayımlanmaktadır ${ }^{1}$. Ayrıca okul yöneticilerinin diğer ülkelerdeki meslektaşları ile iletişime geçebilmeleri ve karşılıklı deneyim paylaşımında bulunabilmeleri için başta İngilizce olmak üzere bir ikinci dili iyi düzeyde kullanabilmeleri gerekmektedir.

Tablo 2

Okul Yöneticilerinin Bildiği Yabancı Diller ve Düzeylerinin Frekans ve Yüzdeleri

\begin{tabular}{lcccccc}
\hline & \multicolumn{2}{c}{ İngilizce } & \multicolumn{2}{c}{ Diğer } & \multicolumn{2}{c}{ Toplam } \\
\cline { 2 - 7 } & $f$ & $\%$ & $f$ & $\%$ & $f$ & $\%$ \\
\hline Çok İyi & 32 & 10.3 & 7 & 2.3 & 39 & 12.6 \\
\hline Orta & 84 & 27.1 & 12 & 3.9 & 96 & 31.0 \\
\hline Zayıf & 155 & 50.0 & 20 & 6.5 & 175 & 56.5 \\
\hline Toplam & 271 & 87.4 & 39 & 12.6 & 310 & 100 \\
\hline
\end{tabular}

Tablo 2'de görüldüğü gibi araştırmaya katılan okul yöneticilerinin \% 87.4'ü İngilizce bildiğini söylese de bunların sadece \%10.3'ü İngilizceyi çok iyi bildiğini belirtmiştir. Ayrıca İngilizceyi iyi derecede bildiğini belirten katılımcıların çoğunluğu 15 yıl yöneticilik kıdemine sahiptir ve genellikle müdür yardımcılığı görevindedir. Okul yöneticilerinin büyük çoğunluğu İngilizce yayınları özgün dillerinden takip etme ve yabancı meslektaşlarıyla kişisel olarak iletişim kurma şansına sahip değildir.

\section{Durumu}

Okul Yöneticilerinin Eğitim Yönetimi Alanında Özel Bir Eğitim Alma

Türkiye'de okul yöneticiliği henüz bir meslek olarak tanımlanmamışsa da görevin, ilgili yönetmeliklerde öğretmenlik yeterliklerine ek sorumluklar gerektirdiği belirtilmektedir (MEB, 2009). Bu görevi üstlenecek kişilerin, görevin gerektirdiği sorumlukları yerine getirebilmeleri özel bir eğitim ihtiyacını ortaya çıkarmaktadır (Turan ve Şişman, 1999). Katılımcıların eğitim yönetimi alanında eğitim alma durumları Tablo 3 'te görülmektedir.

1 TUBITTAK tarafından hazırlanan ULAKBİM'de eğitim yönetimi ve okul yöneticiliği alanında bilimsel çalışmaları yayımlayan ulusal ve uluslararası hakemli dergiler listelenmektedir. Bu dergilerden çok azı eğitim yönetimi alanında Türkçe ve İngilizce makaleler yayımlamakta, diğer dergiler ise sadece İngilizce makaleler yayımlamaktadır (http://www.ulakbim.gov.tr). 
Tablo 3

Okul Yöneticilerinin Eğitim Yönetimi Alanında Eğitim Alma Durumlarının Frekans ve Yüzdeleri

\begin{tabular}{lcc}
\hline & $f$ & $\%$ \\
\hline Eğitim almadım. & 118 & 38.1 \\
\hline 3 aydan kısa süreli bir kursa katıldım. & 99 & 31.9 \\
\hline Lisans eğitimi aldım. & 48 & 15.5 \\
\hline Yüksek lisans eğitimi aldım. & 37 & 11.9 \\
\hline Doktora eğitimi aldım. & 4 & 1.3 \\
\hline 3 aydan uzun süreli bir kursa devam ettim. & 4 & 1.3 \\
\hline Toplam & 310 & 100 \\
\hline
\end{tabular}

Araştırmaya katılan okul yöneticilerinin \%38.1'i eğitim yönetimi ile ilgili herhangi bir eğitim almadığını belirtmiştir. Okul yönetimi ile ilgili üç aydan kısa süreli bir eğitim aldığını belirtenlerin oranı ise \%31.9'dur. Üç aydan kısa süreli eğitimler MEB'in 1998'de yayınladığı yönetmelikle yeni atanan yöneticilere zorunlu tuttuğu 120 saatlik eğitimi kapsamaktadır. Ayrıca bazı hizmetiçi eğitimler, seminerler, kurslar da bu gruba dahildir. Lisans eğitimi aldığını belirtenlerin (\%15.5) bir kısmı eğitim yönetimi ve denetimi lisans programlarından mezun olmuş büyük bir kısmı ise eğitim fakültelerinde verilen formasyon dersleri içinde yer alan Okul Yönetimi ve Türk Eğitim Sistemi adlı dersi bu kategoride belirtmiştir. Eğitim yönetimi alanında yüksek lisans eğitimini tamamlayanların oranı \%11.9, doktora yapanların oranı $\% 1.3$ ve üç aydan uzun süreli bir eğitim alanların oranı ise \%1.3'tür. Okul yöneticilerinin \%85.5'i ya eğitim almamış ya da çok kısa süreli bir eğitime tabi olmuşlardır. Bu durum Türkiye'de okul yöneticiliğinin büyük oranda mesleğe başladıktan sonra ve deneme yanılma yoluyla öğrenildiğini göstermektedir. Bununla beraber lisansüstü eğitimi alanların oranının (\%13.2) azımsanmayacak düzeyde olduğu söylenebilir. Eğitim yöneticiliği alanında lisansüstü eğitimini tamamlamış olanların çoğunluğunun yöneticilikte 1-5 yıl kıdeme sahip müdür yardımcılarından oluşuyor olması da bu alandaki lisansüstü eğitimlerin son yıllarda yaygınlaşmasının bir sonucu olduğu görülmektedir.

\section{Okul Yöneticileri ile Eğitim Yönetimi Alanında Yapılan bilimsel Çalışmalar ve Çalışan Bilim İnsanları Arasındaki İlişkinin Niteliği}

$\mathrm{Bu}$ bölümde yer alan bulgular, uygulamacılar olarak okul yöneticileri ile kuramcılar olarak eğitimbilimcilerin ilişki sıklığı, ilişki kanalları, ilişki gerekçeleri ve eğitim yöneticiliği yeterliliklerini edinme kaynaklarını içermektedir. 
Tablo 4

Okul Yöneticilerinin Eğitim Yönetimi Alanındaki Bilimsel Çalışmaları ve Bilim Insanlarını İleme Frekansları ve Yüzdeleri

\begin{tabular}{lcc}
\hline & $f$ & $\%$ \\
\hline Hiç izlemiyorum & 91 & 29.4 \\
\hline En fazla dönemde bir kez & 70 & 22.6 \\
\hline En fazla yılda bir kez & 59 & 19.0 \\
\hline En fazka ayda bir kez & 48 & 15.5 \\
\hline Sürekli izliyorum & 42 & 13.6 \\
\hline Toplam & 310 & 100.0 \\
\hline
\end{tabular}

Tablo 4'te görüldüğü gibi katılımcıların \%29.4'ü eğitim yönetimi alanında yapılan bilimsel araştırmalara ve eğitim yönetimi alanındaki bilim insanlarına hiç müracaat etmediklerini belirtmişlerdir. Y1lda (19.0) ya da dönemde (22.6) en fazla bir kez müracaat edenlerin oranı da eklendiğinde (\%70.9) okul yöneticilerinin büyük çoğunluğunun alana ilişkin bilimsel çalışmalara ve bilim insanlarına düzenli olarak müracaat etmedikleri söylenebilir. Okul yöneticilerinin \%29.1'i ise en az ayda bir ya da sürekli bilimsel çalışmalara ve bilim insanlarına müracaat ettiklerini belirtmişlerdir.

Katılımcıların eğitim yönetimi alanındaki bilimsel çalışmaları ve bilim insanlarını hangi yollarla ulaştıklarına dair bulgular Tablo 5 'te yer almaktadır. 


\section{Tablo 5}

Okul Yöneticilerinin Eğitim Yönetimi Alanındaki Bilimsel Çalışmalara ve Bilim Insanlarına Ulaşma Yollarının Frekansları ve Yüzdeleri*

\begin{tabular}{lcc}
\hline & $f$ & $\%$ \\
\hline İnternetten & 176 & 56.8 \\
\hline Bilimsel toplantılara katılarak (kongre. sempozyum. çalıştay. seminer vb.) & 103 & 33.2 \\
\hline Kitaplardan & 78 & 25.2 \\
\hline Akademik dergilerden & 44 & 14.2 \\
\hline Gazetelerden & 39 & 12.6 \\
\hline Televizyondan & 33 & 10.6 \\
\hline Üniversiteye giderek & 21 & 6.8 \\
\hline Okula davet ederek & 20 & 6.5 \\
\hline Popüler dergilerden & 11 & 3.5 \\
\hline Diğer & 8 & 2.6
\end{tabular}

*Katılımcılardan bu soruya birden fazla cevap vermeleri istendiğinden cevap yüzdelerinin toplamı 100 'den fazladir.

Okul yöneticileri bilimsel çalışmaları en fazla Internet (\%56.8) yoluyla ulaşmaktadırlar. Internet'i sırasıyla bilimsel toplantılar (\%33.2) ve kitaplar (25.2) izlemektedir. Akademik dergiler (\%14.2), gazeteler (\%12.6), televizyon yayınları (\%10.6) ise daha düşük düzeyde olsa da bilimsel çalışmaları izlemek açısından bir yol olarak değerlendirilmektedir. Okul yöneticileri bilimsel çalışmaları izlemek için popüler dergilere (\%3.5) çok az müracaat etmektedir. Bilim insanları ile görüşme yolu olarak ise okula davet etme (\%6.8) veya üniversitede ziyaret etme (\%6.5) şeklinde gerçekleşmekte fakat çok sık gerçekleştirilmemektedir.

Katılımcıların eğitim yönetimi alanındaki bilimsel çalışmaları ve bilim insanlarını hangi gerekçelerle izlediklerine dair bulgular Tablo 6'da yer almaktadır. 


\section{Tablo 6}

Okul Yöneticilerinin Eğitim Yönetimi Alanındaki Bilimsel Çalışmaları İzleme Gerekçelerinin Frekansları ve Yüzdeleri*

\begin{tabular}{lcc}
\hline & $f$ & $\%$ \\
\hline Eğitim alanında yenilikleri takip edebilmek için & 198 & 63.9 \\
\hline Belirli aralıklarla hizmetiçi eğitim (konferans. kurs. seminer vb.) almak için & 116 & 37.4 \\
\hline Okul yönetiminde karşılaştığım krizlere çözüm arayışlarında & 95 & 30.6 \\
\hline Bir proje. yarışma vb. bir çalışmada danışmanlık hizmeti almak için & 67 & 21.6 \\
\hline Mevzuatta değişiklikler olduğunda & 63 & 20.3 \\
\hline Yönetim için vazgeçilmez olduğu için & 35 & 11.3 \\
\hline Diğer & 4 & 1.3
\end{tabular}

*Katılımcılardan bu soruya birden fazla cevap vermeleri istendiğinden cevap yüzdelerinin toplamı 100 'den fazladir.

Okul yöneticileri eğitim yönetimi alanında yapılan bilimsel araştırmaları en çok alandaki yeniliklerden haberdar olmak için (\%63.9) izlediklerini belirtmektedirler. Belirli aralıklarla hizmetiçi eğitim almak isteyenler (\%37.4), okul yönetiminde karşılaştıkları krizlere çözüm arayanlar (\%30.6), bir proje ya da yarışma gibi etkinliklerde danışmanlık hizmetine ihtiyaç duyanlar (\%21.6) ve mevzuatta değişiklik olduğunda bilim insanlarına ya da bilimsel çalışmalara müracaat edenler de (\%20.3) bulunmaktadır. Fakat okul yöneticilerinin çok azı (\%11.3) eğitim yönetimi alanında yapılan araştırmaların ve bilim insanlarının okul yönetimi için vazgeçilmez olduğunu düşünmektedirler.

Katılımcıların eğitim yönetimi alanındaki yeterliliklerinin kaynaklarına dair bulgular Tablo 7'de yer almaktadır.

\section{Tablo 7}

Okul Yöneticilerinin Eğitim Yönetimi Alanındaki Yeterliliklerinin Kaynaklarının Frekanslarl ve Yüzdeleri *

\begin{tabular}{lcc}
\hline & $f$ & $\%$ \\
\hline Okuyarak, araştırarak & 219 & 70.6 \\
\hline Özel gezi gözlem ve paylaşımlarda & 68 & 21.9 \\
\hline Kendimi doğuştan yetenekli görüyorum & 23 & 7.4 \\
\hline Üniversitede aldığım derslerde & 22 & 7.1 \\
\hline Diğer & 13 & 4.2
\end{tabular}

*Katılımcılardan bu soruya birden fazla cevap vermeleri istendiğinden cevap yüzdelerinin toplamı 100'den fazladir. 
Araştırmaya katılan okul yöneticilerini okul/eğitim yönetimi alanındaki yeterliliklerini büyük oranda (\%70.6) okuyarak ve araştırarak edindiklerini ifade etmişlerdir. Okul yönetimi alanında kazandığı tecrübe ve yeterliliklerini gezi, gözlem ve paylaşımlarla edinen okul yöneticileri de (\%21.9) azımsanmayacak düzeydedir. Kendini yönetim alanında kabiliyetli görenler (\%7.4) ile üniversitede aldığ 1 dersler sayesinde (\%7.1) yöneticilik becerilerini geliştirdiğini belirtenler ise daha küçük bir grubu oluşturmaktadir.

\section{Okul Yöneticileri ile Eğitim Yönetimi Alanında Yapılan Bilimsel Çalışmalar ve Çalışan Bilim İnsanları arasındaki Engeller}

Okul yöneticileri ile eğitim/okul yönetimi alanında yapılan bilimsel araştırmalar ve alanda çalışma yapan eğitimbilimciler arasındaki ilişkinin önündeki engellerin belirlenmesine yönelik bulgular dört alt başlık altında incelenmiştir.

\section{Bilimsel araştırmaların niteliğinden kaynaklanan engeller}

Okul yöneticilerinin bilimsel çalışmaların niteliğine ilişkin görüşlerine bakıldığında ankette yer alan bu konuyla ilgili yedi maddenin tamamına her üç katılımcıdan biri net bir cevap vermekten kaçınmıştır. Bu durum bilimsel araştırmaları ve bilim insanlarını izlemeyenlerin oranıyla karşılaştırıldığında düşük gibi görünse de iki durum arasında oldukça yüksek bir ilişki olduğu söylenebilir. 
Tablo 8

Bilimsel Araştırmaların Niteliğinden Kaynaklanan Engellerin Frekans ve Yüzdeleri

\begin{tabular}{|c|c|c|c|c|c|c|c|c|c|c|c|}
\hline & \multicolumn{2}{|c|}{$\begin{array}{c}\text { Kesinlikle } \\
\text { Katılmiyorum }\end{array}$} & \multicolumn{2}{|c|}{ Katılmiyorum } & \multicolumn{2}{|c|}{ Belki } & \multicolumn{2}{|c|}{ Katıliyorum } & \multicolumn{2}{|c|}{$\begin{array}{l}\text { Tamamen } \\
\text { Katıliyorum }\end{array}$} & Ortalama \\
\hline & $f$ & $\%$ & $f$ & $\%$ & $f$ & $\%$ & $f$ & $\%$ & $f$ & $\%$ & $\overline{\mathrm{X}}$ \\
\hline $\begin{array}{l}\text { Okul yönetimiyle ilgili bilimsel } \\
\text { araştırmaların dilini anlamakta } \\
\text { güçlük çekiyorum. }\end{array}$ & 83 & 26.8 & 122 & 39.4 & 76 & 24.5 & 25 & 8.1 & 4 & 1.3 & 2.18 \\
\hline $\begin{array}{l}\text { Okul yönetimiyle ilgili bilimsel } \\
\text { araştırmalar benim karşı karşıya } \\
\text { kaldığım sorunları ele almıyor. }\end{array}$ & 35 & 11.3 & 72 & 23.2 & 119 & 38.4 & 71 & 22.9 & 13 & 4.2 & 2.85 \\
\hline $\begin{array}{l}\text { Okul yönetimiyle ilgili bilimsel } \\
\text { araştırmalarda tercih edilen } \\
\text { araştırma yöntemlerini yeterli } \\
\text { bulmuyorum. }\end{array}$ & 25 & 8.1 & 74 & 23.9 & 96 & 31.0 & 89 & 28.7 & 26 & 8.4 & 3.05 \\
\hline $\begin{array}{l}\text { Okul yönetimi alanında yapılan } \\
\text { araştırmaları özgün ve yenilikçi } \\
\text { bulmuyorum. }\end{array}$ & 29 & 9.4 & 75 & 24.2 & 94 & 30.3 & 88 & 28.4 & 24 & 7.7 & 3.01 \\
\hline $\begin{array}{l}\text { Okul yönetimiyle ilgili bilimsel } \\
\text { araştırmalarda ele alınan } \\
\text { örneklerin gerçekle ilgisini } \\
\text { kurmakta güçlük çekiyorum. }\end{array}$ & 33 & 10.6 & 83 & 26.8 & 91 & 29.4 & 78 & 25.2 & 25 & 8.1 & 2.93 \\
\hline $\begin{array}{l}\text { Okul yönetimiyle ilgili bilimsel } \\
\text { araştırmalarda sunulan önerileri } \\
\text { uygulanabilir bulmuyorum. }\end{array}$ & 17 & 5.5 & 67 & 21.6 & 111 & 35.8 & 84 & 27.1 & 31 & 10.0 & 3.15 \\
\hline $\begin{array}{l}\text { Okul yönetimiyle ilgili bilimsel } \\
\text { araştırmalarda atıf yapılan } \\
\text { kaynakların uygun ve geçerli } \\
\text { olmadığını düşünüyorum. }\end{array}$ & 27 & 8.7 & 105 & 33.9 & 101 & 32.6 & 62 & 20.0 & 15 & 4.8 & 2.78 \\
\hline
\end{tabular}

Tablo 8'de görüldüğü gibi yedi maddeye net cevap veren katılımcıların büyük çoğunluğunun (\%66.2) bilimsel çalışmalarını dilini anlamakta bir sorun yaşamadığ görülmektedir. Alanla ilgili yapılan bilimsel araştırmaların okul yöneticilerinin karşı karşıya kaldığı sorun alanlarına odaklanıp odaklanmadığı konusundaki madde katılımcıların en yüksek düzeyde (\%38.4) kararsız kaldıkları maddedir. Yaklaşık her üç katılımcıdan birinin ise (34.5) olumlu cevap vermiş olması dikkat çekicidir. Okul yöneticilerinin \%37.1'i bilimsel çalışmalarda kullanılan yöntemlerin yeterli olmadığını, \% 36.1'nin çalışmaların yenilikçi ve özgün olmadığını, \%37.1'nin araştırmalarda sunulan önerilerin uygulanabilir olmadığını ifade etmektedirler. Bununla beraber katılımcıların \%37.4'ü örneklerin gerçek deneyimleri ile ilişkisini kurabilmekte ve $\% 42.6$ 'sı ise araştırmalarda kullanılan kaynakların uygun ve geçerli olduğunu düşünmektedirler. 


\section{Eğitim bilimcilerden kaynaklanan engeller}

Okul yöneticilerinin, alanda çalışma yapan bilim insanlarına ilişkin görüşleri, bilimsel çalışmaların niteliğine ilişkin görüşleri ile kıyaslandığında daha olumsuzdur.

Tablo 9

Ĕ̈itim Bilimcilerden Kaynaklanan Engellerin Frekans ve Yüzdeleri

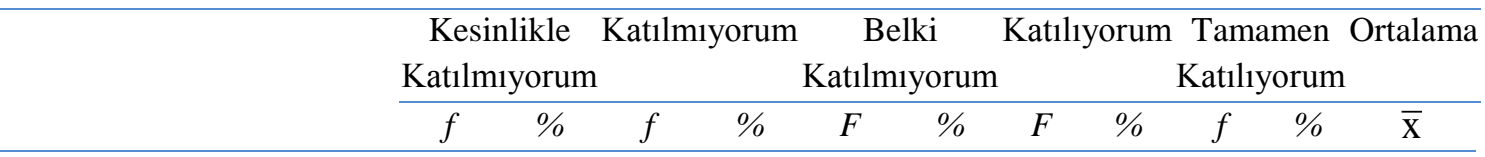

Okul yönetimiyle ilgili

bilimsel araştırma yapan

$\begin{array}{llllllllllll}\text { araştırmacılar okul hayatını } & 17 & 5.5 & 55 & 17.7 & 78 & 25.2 & 100 & 32.3 & 60 & 19.4 & 3.42\end{array}$

yakından tanıma çabası

göstermemektedirler.

Okul yönetimiyle ilgili

bilimsel araştırmalarda

araştırmacıların dünya

görüşlerini çalışmalarına

19

$\begin{array}{llll}6.1 & 54 & 17.4 & 79\end{array}$

$25.5 \quad 122 \quad 39.4$

3611.6

3.33

yansıttıklarını

düşünüyorum.

Okul yönetimiyle ilgili

bilimsel araştırmalar

$\begin{array}{llllllllllll}\text { kamuoyuyla paylaşılırken } & 27 & 8.7 & 74 & 23.9 & 75 & 24.2 & 110 & 35.5 & 24 & 7.7 & 3.10\end{array}$

kullanılan sunum

biçimlerini beğenmiyorum.

Okul yönetimi alanında

araştırma yapan bilim

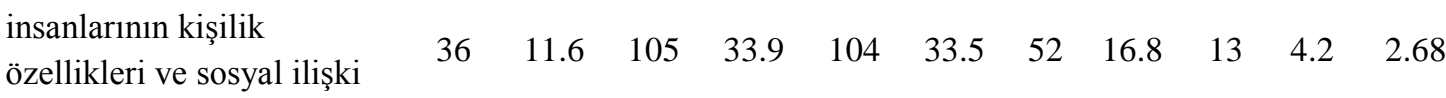

biçimleri bana sıcak

gelmiyor.

Tablo 9'da görüldüğü gibi alanda çalışma yapan bilim insanlarının okul hayatını yakından tanıma çabası göstermediklerini (\%51.7), dünya görüşlerini çalışmalarına yansıttıklarını (\%51.0), bilimsel çalışmalarını sunum biçimlerinin çekici olmadığını (\%43.2) belirtmişlerdir. Bilim insanlarının kişilik özellikleri ve sosyal ilişki biçimleri ise diğer unsurlara göre daha az (\%21.0) olumsuz etkide bulunmaktadır.

\section{Okul yöneticilerinden kaynaklanan engeller}

Okul yöneticilerinin eğitim yönetimi alanında yapılan bilimsel çalışmalara ve bilim insanlarına ulaşmalarında kendilerinden kaynaklanan bazı sorunların da olduğu görülmektedir. 
Tablo 10

Okul Yöneticilerinden Kaynaklanan Engellerin Frekans ve Yüzdeleri

\begin{tabular}{|c|c|c|c|c|c|c|c|c|c|c|c|}
\hline & \multirow{2}{*}{\multicolumn{2}{|c|}{$\begin{array}{c}\text { Kesinlikle } \\
\text { Katılmiyorum }\end{array}$}} & \multirow{2}{*}{\multicolumn{2}{|c|}{ Katılmiyorum }} & \multirow{2}{*}{\multicolumn{2}{|c|}{$\begin{array}{c}\text { Belki } \\
\text { Katılmiyorum }\end{array}$}} & \multirow{2}{*}{\multicolumn{2}{|c|}{ Katıliyorum }} & \multicolumn{3}{|c|}{ Tamamen Ortalama } \\
\hline & & & & & & & & & Katıl & rorum & \\
\hline & $f$ & $\%$ & $f$ & $\%$ & $f$ & $\%$ & $F$ & $\%$ & $f$ & $\%$ & $\overline{\mathrm{X}}$ \\
\hline $\begin{array}{l}\text { Okul yönetimi ile ilgili } \\
\text { bilimsel araştırmalara } \\
\text { ulaşmakta güçlük } \\
\text { çekiyorum. }\end{array}$ & 49 & 15.8 & 110 & 35.5 & 71 & 22.9 & 65 & 21.0 & 15 & 4.8 & 2.64 \\
\hline $\begin{array}{l}\text { Okul yönetimi ile ilgili } \\
\text { bilimsel insanlarına } \\
\text { ulaşmakta güçlük } \\
\text { çekiyorum. }\end{array}$ & 26 & 8.4 & 82 & 26.5 & 66 & 21.3 & 98 & 31.6 & 38 & 12.3 & 3.13 \\
\hline $\begin{array}{l}\text { Okul yönetimi alanında } \\
\text { yapılan araştırmaları } \\
\text { izlemek için yeterli maddi } \\
\text { kaynağım yok. }\end{array}$ & 31 & 10.0 & 72 & 23.2 & 75 & 24.2 & 72 & 23.2 & 60 & 19.4 & 3.19 \\
\hline $\begin{array}{l}\text { Okul yönetimi alanında } \\
\text { yapılan araştırmaları } \\
\text { izlemek için zaman } \\
\text { bulamıyorum. }\end{array}$ & 37 & 11.9 & 94 & 30.3 & 82 & 26.5 & 70 & 22.6 & 27 & 8.7 & 2.86 \\
\hline $\begin{array}{l}\text { Okul yönetiminin bilimsel } \\
\text { araştırmalar ışığında } \\
\text { iyileştirileceğini } \\
\text { düșünmüyorum. }\end{array}$ & 81 & 26.1 & 99 & 31.9 & 62 & 20.0 & 51 & 16.5 & 17 & 5.5 & 2.43 \\
\hline
\end{tabular}

Tablo 10'da görüldüğü gibi katılımcıların \%51.3'ü bilimsel araştırmalara ulaşmakta güçlük çekmediklerini, fakat \%43.9'u bilim insanlarına ulaşmanın zor olduğunu düşünmektedirler. \%42.2'si bilimsel araştırmaları izlemek için zaman sorunu yaşamadığını ifade etmiştir. Ayrıca katılımcıların \%57.0'si okul yöneticiliğinin bilimsel araştırmalar 1şığında iyileştirilebileceğine inanmaktadır. Ne var ki bazı katılımcılar bilimsel araştırmalara ulaşsa bile maddi kaynağının yeterli olmadığını (\%42.6) belirtmiştir.

\section{Diğer Engeller}

Okul yöneticilerine, bilimsel araştırmalarda yer alan önerileri okul yönetimine uygulamalarına engel olan diğer faktörlerin neler olduğu da sorulmuştur. 
Tablo 11

Diğer Etkenlerden Kaynaklanan Engellerin Frekans ve Yüzdeleri

\begin{tabular}{|c|c|c|c|c|c|c|c|c|c|c|c|}
\hline & \multirow{2}{*}{\multicolumn{2}{|c|}{$\begin{array}{c}\text { Kesinlikle } \\
\text { Katılmıyorun }\end{array}$}} & \multirow{2}{*}{\multicolumn{2}{|c|}{ Katılmiyorum }} & \multirow{2}{*}{\multicolumn{2}{|c|}{$\begin{array}{c}\text { Belki } \\
\text { Katılmiyorum }\end{array}$}} & \multirow{2}{*}{\multicolumn{2}{|c|}{ Katıliyorum }} & \multirow{2}{*}{\multicolumn{2}{|c|}{$\begin{array}{c}\text { Tamamen } \\
\text { Katıliyorum }\end{array}$}} & \multirow[t]{2}{*}{ Ortalama } \\
\hline & & & & & & & & & & & \\
\hline & $f$ & $\%$ & $f$ & $\%$ & $f$ & $\%$ & $f$ & $\%$ & $f$ & $\%$ & $\overline{\mathrm{x}}$ \\
\hline $\begin{array}{l}\text { Okul yönetimiyle ilgili } \\
\text { bilimsel araştırma } \\
\text { sonuçlarını uygulamaya } \\
\text { yansıtmak istediğimizde } \\
\text { mevzuat elimizi } \\
\text { bağlamaktadır. }\end{array}$ & 12 & 3.9 & 51 & 16.5 & 83 & 26.8 & 92 & 29.7 & 72 & 23.2 & 3.52 \\
\hline $\begin{array}{l}\text { Okul yönetimiyle ilgili } \\
\text { bilimsel araştırmaları } \\
\text { uygulamaya yansıtmak } \\
\text { istediğimde üstlerimin } \\
\text { dirençlerini aşamıyorum. }\end{array}$ & 14 & 4.5 & 80 & 25.8 & 99 & 31.9 & 73 & 23.5 & 44 & 14.2 & 3.17 \\
\hline $\begin{array}{l}\text { Okul yönetimiyle ilgili } \\
\text { bilimsel araştırmaları } \\
\text { uygulamaya yansıtmak } \\
\text { istediğimde astlarımın } \\
\text { dirençlerini aşamıyorum. }\end{array}$ & 35 & 11.3 & 86 & 27.7 & 110 & 35.5 & 57 & 18.4 & 22 & 7.1 & 2.82 \\
\hline $\begin{array}{l}\text { Okul yönetimiyle ilgili } \\
\text { bilimsel araştırmaları } \\
\text { uygulamaya yansıtmak } \\
\text { istediğimde veli ve okul } \\
\text { yakın çevresinin direnciyle } \\
\text { karşış̧ıyorum. }\end{array}$ & 34 & 11.0 & 84 & 27.1 & 103 & 33.2 & 69 & 22.3 & 20 & 6.5 & 2.86 \\
\hline
\end{tabular}

Tablo 11'de görüldüğü gibi katılımcıların \%52.9'u mevzuatın, \%37.7'si üstlerinin/amirlerinin kendilerini engellediğini düşünmektedir. Katılımcılar astlarının (\%25.5) ve veli ve okul dış1 çevrenin ise (\%28.7) daha az engelleyici olduğunu belirtmişlerdir.

\section{Bilim İnsanları}

Okul Yöneticilerinin Son Bir Yıl İçinde Ulaştıkları Bilimsel Çalışmalar ve

Araştırmanın son sorusu olan okul yöneticilerinin son bir yıl içinde ulaştıkları bilimsel çalışmalar ve bilim insanların sayısı ve niteliği belirlemek amacıyla katılımcılara iki açık uçlu soru yöneltilmiştir. Bu sorulardan ilki, 2010-2011 eğitim öğretim yılı içinde bir vesile ile iletişimde bulundukları eğitim bilimcinin ad, ikincisinde ise 2010-2011 eğitim öğretim yılında okudukları eğitim yönetimi ile ilgili eser adıdır. Katılımcılara en fazla üç isim ya da eser yazabilecekleri belirtilmiştir. Buna rağmen katılımcıların çoğunluğu bu soruları hiç yanıtlamamıştır. Yanıtlayan katılımcıların verdiği cevaplara ilişkin bulgular Tablo 12 ve Tablo 13 'te görülmektedir. 


\section{Tablo 12}

Okul Yöneticilerinin Son Öğretim Yılı Iç̧inde İlişkide Oldukları Ĕ̈itim Bilimciler

\begin{tabular}{llc}
\hline İlişki kurulan bilim insanının alanı & $f$ & $\%$ \\
\hline EYTPE Anabilim Dalından & 14 & 4.2 \\
\hline Eğitim Bilimleri Bölümünden (EYTPE hariç) & 12 & 3.9 \\
\hline Eğitim Fakültelerinden (Eğitim Bilimleri bölümü hariç) & 11 & 3.5 \\
\hline Eğitim Fakültesi Dışından & 14 & 0.6 \\
\hline Akademi Dışından & 2 & 0.9 \\
\hline Diğer & 3 & 82.3 \\
\hline Cevapsız & 255 & 100 \\
\hline Toplam & 310 & \multirow{2}{*}{} \\
\hline
\end{tabular}

Okul yöneticilerine son öğretim yılı içinde bir şekilde ilişki kurdukları eğitim bilimcileri yazmaları amacıyla açık uçlu bir soru sorulmuştur. Bu soruya katılımcıların $\% 82.3$ 'ü herhangi bir cevap yazmamıştır. Katılımcıların \%11.6'sı eğitim fakültelerinde görevli herhangi bir öğretim elemanının ismini yazarken bunlardan sadece \%4.2'si EYTPE anabilim dalında görevlidir. Katılımcıların \%6.1'i ise eğitim fakültesi dışından ya da akademisyen olmayan kişilerin isimlerini belirtmişlerdir. 
Tablo 13

Okul Yöneticilerinin Son Öğretim Yılı Iç̧inde Okudukları Eğitim Yönetimi ile Illgili Eserler

\begin{tabular}{lcc}
\hline Okunan eserin konusu / alanı & $f$ & $\%$ \\
\hline Eğitim ve Okul Yönetimi & 18 & 5.8 \\
\hline Yönetim & 4 & 1.3 \\
\hline Eğitim Bilimleri & 14 & 4.5 \\
\hline Genel Kültür & 2 & 0.6 \\
\hline Dergi / Gazete Yazıları & 8 & 2.6 \\
\hline Diğer & 2 & 0.6 \\
\hline Cevapsız & 262 & 84.6 \\
\hline Toplam & 310 & 100 \\
\hline
\end{tabular}

Okul yöneticilerine son öğretim yılı içinde okumuş oldukları okul/eğitim yönetimi ile ilgili kitapların/eserlerin isimlerini yazmaları amacıyla açık uçlu bir soru sorulmuştur. $\mathrm{Bu}$ soruya katılımcıların \%84.6'sı herhangi bir cevap yazmamıştır. Katılımcıların \%11.6'sı eğitim yönetimi, yönetim ya da eğitim bilimleri alanında bir kitap ismini yazarken bunlardan sadece \%5.8'i okul/eğitim yönetimi konulu kitaplardır. Katılımcıların \%3.8'i ise konusu eğitim yönetimi, yönetim ve eğitim olmayan kitapların/eserlerin isimlerini yazmıştır.

\section{Sonuç ve Tartışma}

Okulların hedeflerini gerçekleştirmesinde okul yöneticilerinin oldukça önemli etkileri olduğu birçok bilimsel çalışma ile ortaya konmuştur (Marzano, Waters ve McNulty, 2005). Okul yöneticilerinin bu başarıyı gerçekleştirebilmeleri için bazı özel bilgi, beceri ve değerlere sahip olmaları gerektiği bilinmektedir (Turan ve Şişman, 1999). Ayrıca okul yöneticiliğinin son 20-30 yılda çok önemli bir değişim geçirdiği ve bu değişim dalgasının okul yöneticilerinin üstlendikleri görevin zorluğunu daha da artırdığı belirtilmektedir. Değişimin merkezinde artan okul özerkliği, çıktılara ilişkin daha fazla hesap verme zorunluluğu ve öğrenme merkezli bir liderlik ihtiyac1 sayılmaktadır (Pont, Nusche ve Moorman, 2008). Bütün bu gerekçeler okul yöneticilerinin hizmet öncesi ve hizmete girişte nitelikli ve göreve uygun bir içeriğe sahip hazırlayıcı eğitim almalarını zorunlu kılmakta ve ayrıca sürekli bir mesleki gelişme içinde olmalarını gerektirmektedir (Pont, Nusche ve Moorman, 2008). Okul yöneticilerinin sürekli mesleki gelişimleri, belirli zamanlarda ve belirli konulara odaklanan yüz yüze ya da uzaktan eğitim yanında kendi kendilerine, sürekli ve ihtiyaç 
duydukları her an ulaşabilecekleri bilimsel çalışmalara dayalı ve uygulamada sorunlarını çözecek nitelikte materyal ve diğer imkanlarla bizzat görev başında olmalıdır. Bu ihtiyaç okul yöneticilerinin eğitim yönetimi alanında yapılan bilimsel araştırmalara mütemadiyen ulaşmalarını ve bilim insanları ile irtibat halinde olmalarını gerektirir.

Araştırmanın "Okul yöneticileri hangi yabancı dilleri ne düzeyde bilmektedirler?" şeklindeki ilk sorusuna ilişkin sonuçlara bakıldığında araştırmaya katılan okul yöneticilerinin büyük çoğunluğu (\%86.5) İngilizceyi, bilimsel çalışmaları takip edecek ve yabancı meslektaşlarıyla iletişim kuracak düzeyde bilmedikleri görülmektedir. Bu durum alana ilişkin Türkçe yayınların, araştırmaların önemini bir kat daha artırmaktadır.

Araştırmanın "Okul yöneticileri, eğitim yönetimi alanında ne tür bir eğitim almışlardır?" şeklindeki ikinci sorusuna ilişkin sonuçlara bakıldığında okul yöneticilerinin büyük çoğunluğunun (\%85.5) eğitim/okul yöneticiliğgine dair bir eğitim almadan göreve başladıkları görülmüştür. Görevleri sırasında da mesleki açıdan kendilerini geliştirecek çok fazla alternatifin olmadığı görülmektedir. Bu durum da okul yöneticilerinin etkili bir eğitim liderliği yapabilmeleri için alanda yapılan bilimsel çalışmalara, geliştirilen kuramlara ulaşabilmeleri ve onlardan istifade etmeleri, sorumluluğunu aldıkları kurumu başarılı bir biçimde yönetebilmeleri için acil bir ihtiyaç olarak görülmektedir.

Araştırmanın "Okul yöneticileri ile eğitim yönetimi alanında yapılan bilimsel çalışmalar ve bilim insanları arasında ne tür bir ilişki bulunmaktadır?” şeklindeki üçüncü sorusuna ilişkin sonuçlar da yukarıdaki bulguları destekler niteliktedir. Okul yöneticilerinin büyük çoğunluğu (\%70.9) eğitim yönetimi alanındaki bilimsel araştırmaları ya hiç izlememektedir ya da çok seyrek izlemektedir. Bununla beraber alanda yapılan bilimsel araştırmaları izlemek için tercih edilen en yaygın yol Internet'tir (\%56.8). Internet'i bilimsel toplantılar (\%33.2) ve kitaplar (\%25.2) izlemektedir. Bu durumda okul/eğitim yönetimi alanında yapılan çalışmalardan okul yöneticilerinin daha fazla istifade etmesini sağlamak amacıyla araştırmaların Internet ortamında paylaşılması, daha sık ve ihtiyaca yönelik bilimsel toplantıların gerçekleştirilmesi ve okul yöneticiliğine ilişkin kuramların uygulamaya nasıl yansıtılacağına odaklanan kitapların sayısının artması gerektiği görülmektedir. Nitekim okul yöneticileri mesleki yeterliliklerini en fazla okuyarak ve araştırarak (\%70.6) kazanmaktadırlar. Diğer yaygın yol ise gezi, gözlem ve paylaşımlardır (\%21.9). Okul yöneticilerinin mesleki yeterliliklerini artırmak amacıyla meslektaş paylaşımlarına imkan verecek buluşmalar düzenlenebilir. ABD'de okul yöneticileri mesleki örgütleri üyelerinin mesleki gelişimlerini sürdürmelerine katkı sağlamak amacıyla Internet'i en yaygın yol olarak kullanmaktadırlar ${ }^{1}$. Diğer taraftan İngiltere'de okul yöneticilerinin mesleki gelişimlerini

1 ABD'de okul yöneticilerinin üye olduğu ulusal mesleki örgütlenmeler olan NASSP, NAESP ve ASCD, ayrıca eyalet bazlı diğer örgütlenmeler görev başındaki okul yöneticilerinin mesleki gelişimlerine destek olmak amacıyla kurumsal web siteleri ve sosyal paylaşım siteleri aracılığıyla sesli, görüntülü ve yazılı materyaller paylaşmaktadırlar. Bu materyal ve paylaşımlar çoğunlukla ücretsizdir (www.nassp.org; www.naesp.org, www.ascd.org). 
sürdürmelerinin bir yolu olarak meslektaş paylaşım toplantıları organize edilmektedir (Balyer ve Gündüz, 2011).

Esasında okul yöneticilerinin çok azı, alanda yapılan bilimsel araştırmaların okul yönetimi için vazgeçilmez olduğuna çok fazla inanmakla (\%11.3) birlikte eğitim alanında meydana gelen gelişmeleri izlemek amacıyla (\%63.9) bilimsel çalışmaları merak ettiklerini belirtmektedirler. $\mathrm{Bu}$ bulgu okul yöneticilerinin üstlendikleri görevin dinamizminin farkında olduklarının ve dolayısıyla öğrenme ve gelişme gereksinimi duyduklarını göstermektedir. Buna rağmen bilimsel çalışmalara ve bilim insanlarına çok fazla ilgi duymuyor olmaları dikkat çekicidir.

Araştırmanın dördüncü sorusu olan okul yöneticilerinin eğitim yönetimi alanında yapılan bilimsel çalışmalara ve bilim insanlarına ulaşmalarını engelleyen unsurlara ilişkin sonuçlara bakıldığında okul yöneticilerinin önemli oranda "belki" şeklinde cevap vermiş olmaları (çoğu madde için bu oran \%30'un üzerindedir) bilimsel çalışmaları ve bilim insanlarını pek fazla izlemiyor olmalarından kaynaklandığı düşünülebilir. Engellerin en çok hangi alanda yoğunlaştığına baktığımızda okul yöneticilerinin bilimsel araştırmaların okuldaki gerçek sorunlara odaklanmadığı (\%38.4), bilim insanlarının okulu yakından tanıma gayretinde olmadıklarını (\%51.7), dünya görüşlerini çalışmalarına yansıttıklarını (\%51.0) ve bilimsel çalışmalarını sunum biçimlerinin çekici olmadığını (\%43.2) belirtmiş olmaları Turan'ın (2010) eğitim yönetimi alanında yapılan bilimsel araştırmalar ve bilim insanları hakkındaki değerlendirmelerini desteklemektedir. Turan'a (2010, xvii) göre eğitim yönetimi alanında yapılan araştırmalar, sağlam teorik temelden ve pratikte karşılaşılan sorunların çözümüne rehberlik edebilme açılarından sorunludur. Ayrıca Özdemir'in (2009) eğitim bilimleri alanında yapılan bilimsel araştırmalarda karşılaşılan sorunlar üzerine yaptı̆̆ araştırmasında ortaya koyduğu bulgular ile Al'ın (2008) Türkiye'deki bilimsel araştırmaların nitelikten çok niceliğe önem verdiğini ortaya koyan araştırmaları da okul yöneticilerinin bilimsel araştırmalara yönelik değerlendirmelerinde haklı olduklarını düşündürmektedir.

Okul yöneticilerinin mevzuatın (\%52.9) ve üstlerinin (\%37.7), bilimsel önerileri uygulamalarında kendilerini engellediğini ifade etmiş olmaları ise eğitim sisteminin yeniliğe ve değişime yapısal olarak direnç göstermesinin ya da en azından uygun olmamasının bir sonucu olabilir. Balcı'nın (2000) tartıştığ yönetim örgütlenmesinin içerdiği sorunların okul yöneticilerinin bu cevaplarıyla ilişkisi üzerinde durulmalıdır. Ayrıca okul yöneticilerinin çoğunlukla bilimsel çalışmalara ulaşmak için yeteri kadar maddi kaynaklarının olmadığını belirtmiş olmaları (\%42.6) OECD raporunda okul yöneticilerinin görevin zorluğu ile uyumlu bir kazanç elde edemedikleri tespitiyle ilişkilendirilebilir (Pont, Nusche ve Moorman, 2008).

Son olarak araştırmanın "Okul yöneticilerinin son bir yıl içinde ulaştıkları eğitim yönetimi alanında yapılan bilimsel çalışma ve bilim insanlarının sayısı ve niteliği nedir?” şeklindeki beşinci sorusunu katılımcıların büyük çoğunluğunun (\%82 ve \%84) cevapsız bırakmış olması esasında kuram ve uygulama arasındaki kopukluğun düzeyini açıkça göstermektedir. 
Araştırma okul yöneticileri, akademisyenler ve eğitim yöneticileri için manidar bulgular sunmaktadır. Okul yöneticilerinin bilimsel bir okul yöneticiliği perspektifi olmadığı açıkça söylenebilir. Alan akademisyenlerinin ise bu ihtiyacı giderecek girişimlerde bulunmadıkları görülmektedir. Bakanlığın ilgili bölümlerle ve okul yöneticileriyle bu durumun çözümüne ilişkin ivedi önlemler alması gerekmektedir. Fakat asıl sorumluluğun akademisyenlere düştüğü söylenebilir. Zira çalışma alanı olarak tercih ettikleri okul/eğitim yönetimi alanında görev yapan okul yöneticilerinin, akademisyenlerin ürettiği onca bilimsel bilgiden habersiz bir biçimde görevlerine devam ediyor olmaları öncelikle akademisyenlerin kullandıkları bilimsel yöntemleri ve çalışma alanlarını yeniden gözden geçirmelerini zorunlu kılmaktadır. Ayrıca üniversitelerin temel işlevlerinden birinin gündelik hayatta karşılaşılan sorunlara çözümler üretmek olduğu unutulmamalıdır (Erdem, 2005).

Diğer taraftan okul yöneticilerinin üstlendikleri göreve ilişkin temel eğitim almadan göreve başlamış olmalarına ve etkili bir hizmet-içi eğitim imkanı da sunulmuyor olmasına rağmen alanlarıyla ilgili bilimsel çalışmaları ve bilim insanlarını izlemiyor olmalarının başka bazı gerekçelerle ilişkili olup olmadığı da araştırılmalıdır. $\mathrm{Bu}$ araştırma ile ortaya çıkan gerekçelere ek olarak okul yöneticilerinin hayat boyu öğrenme isteği ve becerilerinin ve bilimsel okuryazarlık yeterliliklerinin de araştırılması ve bu duruma ne düzeyde etki ettiğinin ortaya çıkarılması gerekmektedir. 


\section{Kaynakça}

Al, U. (2008). Türkiye'nin bilimsel yayın politikası: Atıf dizinlerine dayalı bibliyometrik bir yaklaşım (Yayımlanmamış doktora tezi). Hacettepe Üniversitesi, Ankara, Türkiye.

Bakioğlu, A. ve Özcan, K. (2001). İlköğretim okul yöneticilerinin kariyer gelişimleri. Kuram ve Uygulamada Ĕgitim Bilimleri (1)1, 39-57.

Balc1, A. (2000). İkibinli y1llarda Türk milli eğitim sisteminin örgütlenmesi ve yönetimi. Kuram ve Uygulamada Eğitim Yönetimi, (24). 495-508.

Balyer, A. ve Gündüz, Y. (2011). Değişik ülkelerde okul müdürlerinin yetiştirilmesi: Türk eğitim sistemi için bir model önerisi. Kuramsal Eğitimbilim, 4 (2), 182-197.

Bullough Jr, R. V. \& Kauchak, D. (1997). Partnerships between higher education and secondary schools: Some problems. Journal of Education for Teaching: International Research And Pedagogy, 23(3), 215-234.

Büyüköztürk, Ş. (2005). Anket geliştirme. Türk Eğitim Bilimleri Dergisi, 2(3), 133-148.

Chiu, C. S. (2004). School improvement through a university school partnership: a case study in a Hong Kong primary school (Unpublished doctoral dissertation). The Chinese University of Hong Kong, China.

Demir, Ö. (2000). Bilim felsefesi. Ankara: Vadi yayınları.

Deniz, M. (2001). Milli eğitim şuralarının tarihçesi ve eğitim politikalarına etkileri. (Yayımlanmamış Yüksek Lisans Tezi). Süleyman Demirel Üniversitesi, Isparta, Türkiye.

Doğan, O. (2009). Hizmetiçi ĕgitime katılımın ĕgitim öğretim sürecine etkisi ile ilgili yönetici ve ögretmen görüşleri (Yayımlanmamış yüksek lisans tezi). Maltepe Üniversitesi, İstanbul, Türkiye.

El-Amin, C., Cristol, D. \& Hammond, R. (1999). Constructing a professional development school: A model of one school-university partnership. The Teacher Educator, 35(2), 1-14.

Ensari, H. (2004). 21. yüzyll okulları için toplam kalite yönetimi. İstanbul: Sistem yayıncilik.

Eraslan, A. (2008). Fakülte-okul işbirliği programı: Matematik öğretmen adaylarının okul uygulama dersi üzerine görüşleri. Hacettepe Üniversitesi Eğitim Fakültesi Dergisi, (34), 95-105.

Erdem, A. R. (2005). Üniversitenin varoluş nedeni (Üniversitenin misyonu). Pamukkale Üniversitesi Eğitim Fakültesi Dergisi, (17), 75-86.

Erdoğan, İ. (2004). Okul Yönetimi öğretim liderliği. İstanbul: Sistem yayınc1lık.

Frampton, P., Vaughn, V. L. and Didelot, M. J. (2003). The professional development school partnership: Is practice improving? Teachers and principals respond. Journal of Educational Administration, 41(3), 292 - 309. 
Güngördü, A. (1999). Öğretmenlik deneyimi ve öğretmenlik uygulaması: Fakülte-okul işbirliği. Ĕgitim Yönetimi Dergisi (19), 455-459.

Güzel, H., Cerit Berber, N. ve Oral, İ. (2010). Eğitim fakültesi uygulama okulları işbirliği programında görevli öğretmenlerin ve öğretim elemanlarının öğretmenlik uygulamasına yönelik görüşleri. Kastamonu Ĕ̆itim Dergisi, 18 (1), 19-36.

Hopkins-Malchow, J. M. ( 2009). Perceptions of school faculty, university faculty, and teacher candidates participating in a professional development school partnership (Yayımlanmamış doktora tezi). Ball State University, Muncie, Indiana.

Hoy, W. K. \& Miskel, C. G. (2010). Eğitim yönetimi: Teori, araştırma ve uygulama (S.Turan, Çev). Ankara: Nobel yayınları.

Marzano, R. J., Waters, T., \& McNulty, B. A. (2005). School leadership that works: From research to results. Alexandria, VA: ASCD.

Mayring, P. (2000). Nitel sosyal araştırmaya giriş (A. Gümüş ve M. S. Durgun, Çev). Adana: Baki yayınları.

Mcginley, K. (Ed.) (2006). New bearing in higher education. İstanbul: Fatih Üniversitesi yayınları.

Miller, J. D. (2006). Civic scientific literacy in Europe and The United States. A paper presented to the annual meeting of the world association for public opinion research May 17, Montreal, Canada.

Miller, P. M. \& Hafner, M. M. (2008). Moving toward dialogical collaboration: A critical examination of a university- school-community partnership. Educational Administration Quarterly, 44 (1), 66-110.

Milli Eğitim Bakanlığı [MEB], (1998). Öğretmen adaylarının Milli Eğitim Bakanlığına

bağlı eğitim öğretim kurumlarında yapacakları öğretmenlik uygulamasına ilişkin yönerge. Tebliğler Dergisi, sy. 2493. http://mevzuat.meb.gov.tr/html/102.html, 10 Şubat 2011.

Milli Eğitim Bakanlığı [MEB], (1998). Öğretmen adaylarının Milli Eğitim Bakanlığına bağlı eğitim öğretim kurumlarında yapacakları öğretmenlik uygulamasına ilişkin yönerge. Tebliğler Dergisi, sy. 2493. http://mevzuat.meb.gov.tr/html/102.html, 10 Şubat 2011.

Milli Eğitim Bakanlığı (MEB), (2009). Ortaöğretim kurumları yönetmeliği. Resmi Gazete, Sy 27305, 31 Temmuz 2009.

Milli Eğitim Bakanlığı [MEB], (2012). MEB İnsan Kaynakları Genel Müdürlüğü'nün 31.05.2012 tarihli "Uzaktan Eğitim" konulu yazısı.

Mullen, C. A. \& Hutinger, J. L. (2008). The principal's role in fostering collaborative learning communities through faculty study group development. Theory Into Practice (47)4, 276-28. 
Özcan Ş. ve Bakioğlu, A. (2010). Meta analitik etki analizi: Okul yöneticilerinin hizmetiçi eğitim almalarının göreve etkisi. Hacettepe Üniversitesi Eğitim Fakültesi Dergisi (38), 201-212.

Özdemir, C. (2009, Haziran). Türkiye'de ĕgitim bilimcilerin araştırma süreçlerinde karşılaş̧ıkları sorunlar. I. Uluslararası Eğitim Araştırmaları Kongresinde sunulmuş sözlü bildiri, Çanakkale, Türkiye.

Pont, B., Nusche, D. \& Moorman, H. (2008). Improving school leadership, Volume 1: Policy and practice, Paris: OECD. Retrieved from http://www.oecd.org/edu/preschoolandschool/40545479.pdf.

Seifer, S. D. \& Maurana, C.A. (2000). Developing and sustaining community-campus partnerships: Putting principles into practice. Partnership Perspective, 1(2), 7-10.

Sirotnik, K. A. \& Goodlad, J. I. (1988). School-university partnerships in action: Concepts, cases. Amsterdam Avenue, New York, Ny: Teachers College Press, 1234.

Turan, S. ve Şişman, M. (1999). Okul yöneticileri için standartlar: Eğitim yöneticilerinin bilgi temelleri üzerine düşünceler. B. U. Sosyal Bilimler Enstitüsü Dergisi. 3(4), 68-87.

Whitaker, K. S. (1996). Exploring causes of principal burnout. Journal of Educational Administration, 34(1), 60-71.

Yıldırım, A.(1997). Son beş yılda (1992-1996) Hizmetiçi Eğitim Dairesi Başkanlığınca düzenlenen eğitim yönetimi kurs ve seminerlerinin değerlendirilmesi. Ĕgitim Yönetimi (4). 549-571.

Yükseköğretim Kurulu [YÖK], (1998). YÖK Dünya Bankası fakülte-okul işbirliği kılavuzu. Ankara: Öğretmen Eğitimi Dizisi. 